Images in...

\title{
An unexpected injury - cerebral laceration with stiletto
}

\author{
Hugh Jewsbury, Roger Haslett \\ Ophthalmology Department, HM Stanley Hospital, St Asaph, Clwyd, UK \\ Correspondence to Dr Hugh Jewsbury, hughjewsbury@hotmail.com
}

\section{DESCRIPTION}

A 43-year-old woman presented to accident and emergency after being assaulted. During the incident she was stamped on the head with a stiletto. On examination, she was described as being 'intoxicated' but denied drinking or illicit drug use. However, her Glasgow coma score remained fifteen throughout. A small, left upper lid laceration was noted and sutured. No other injuries were detected and consequently she was discharged. One month later she re-presented with diplopia and headaches. She also complained of mild expressive dysphasia and irritability. Examination of her ocular motility revealed a pattern consistent with an acquired Brown's syndrome. CT and MRI were requested (figures 1 and 2) which showed a comminuted fracture of the left medial orbital roof and a cerebral laceration of the left frontal lobe extending to the anterior horn of the lateral ventricle. No form of radiological imaging was requested at presentation. Consequently, a serious intracranial injury was missed. Plain orbital $\mathrm{x}$-rays may have demonstrated the fracture and CT/MRI of the orbits and brain would have conclusively revealed an abnormality. Had the true extent of the patient's injuries been known, her management would have changed considerably. At a minimum she would not have been discharged, she would have been treated with broad spectrum antibiotics and a neurosurgical opinion would have

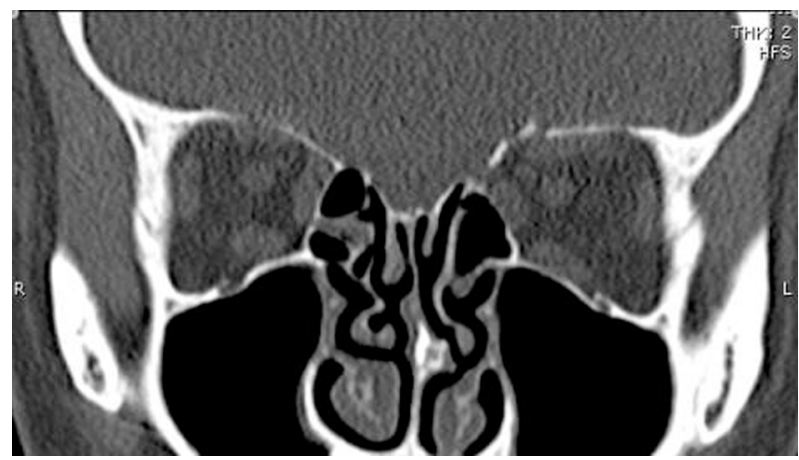

Figure 1 CT showing comminuted fracture of the left, medial orbital roof. been sought. Retrospectively, this event was clearly a 'near miss'. Apparently, innocuous wounds may conceal serious injuries that can easily be missed if radiological imaging is not performed following peri-ocular injuries sustained by sharp objects.

\section{Competing interests None}

Patient consent Obtained

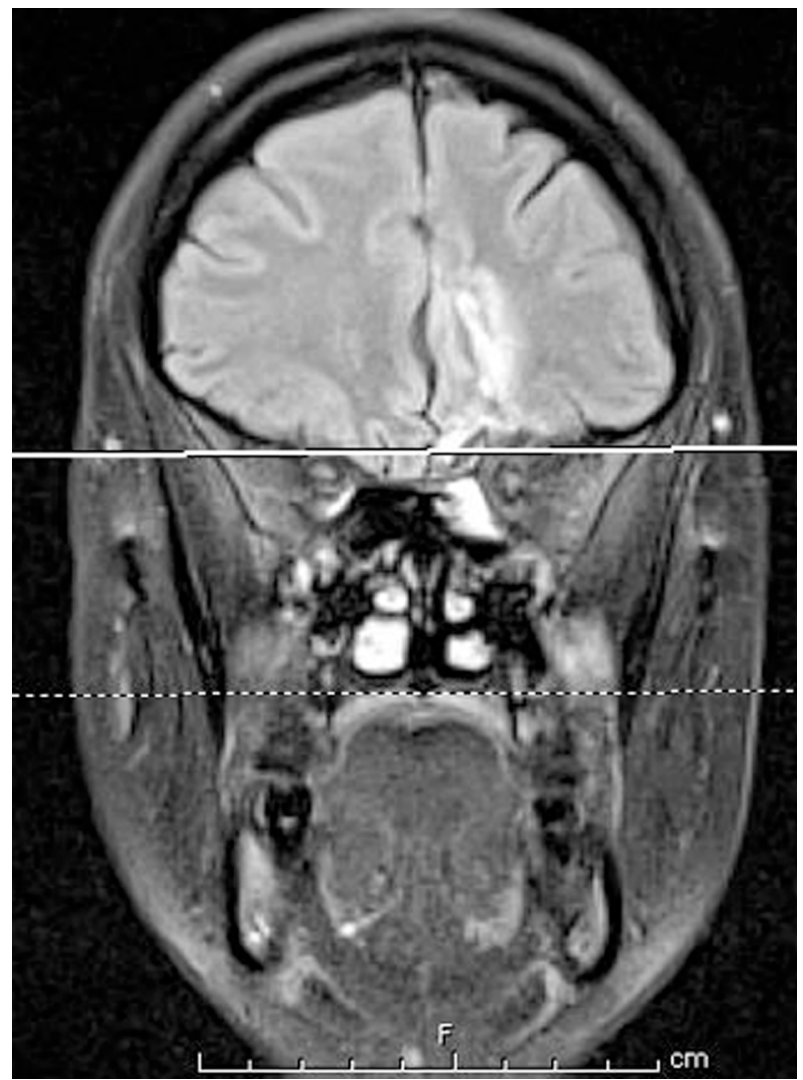

Figure 2 MRI demonstrating a cerebral laceration of the left frontal lobe with associated gliosis and old parenchymal haemorrhage. 


\section{BMJ Case Reports}

This pdf has been created automatically from the final edited text and images.

Copyright 2011 BMJ Publishing Group. All rights reserved. For permission to reuse any of this content visit http://group.bmj.com/group/rights-licensing/permissions.

BMJ Case Report Fellows may re-use this article for personal use and teaching without any further permission.

Please cite this article as follows (you will need to access the article online to obtain the date of publication).

Jewsbury H, Haslett R. An unexpected injury - cerebral laceration with stiletto. BMJ Case Reports 2011;10.1136/bcr.06.2011.4399, date of publication

Become a Fellow of BMJ Case Reports today and you can:

- Submit as many cases as you like

- Enjoy fast sympathetic peer review and rapid publication of accepted articles

- Access all the published articles

- Re-use any of the published material for personal use and teaching without further permission

For information on Institutional Fellowships contact consortiasales@bmjgroup.com

Visit casereports.bmj.com for more articles like this and to become a Fellow 